\title{
VENTILATION SYSTEM WITH GROUND HEAT EXCHANGER
}

\author{
Vyacheslav Pisarev' ${ }^{1}$, Sławomir Rabczak' ${ }^{1}$, Krzysztof Nowak ${ }^{1}$ \\ 1 Faculty of Civil, Environmental Engineering and Architecture, Rzeszow University of Technology, Rzeszow, \\ Poland, e-mail: rabczak@prz.edu.pl; krzynow@prz.edu.pl
}

Received: 2016.08.16 Accepted: 2016.09 .26 Published: 2016.11.01

\begin{abstract}
Ventilation systems consume more and more energy because of the often complex treatment of the air supplied to closed spaces. Looking for sources of energy allow for significant savings costs, which often translate into renewable energy sources. One of the more popular solutions is to use energy from the ground by various methods. Known and relatively common solutions are based on ground heat exchanger and ground collector cooperating with a heat pump. The paper presents the possibility of cooperation ventilation system with ground air heat exchanger and heat pump both in summer and winter period. A number solutions of this type of system, supported by calculation examples and moist air transformation in the Moliere chart have been presented. Support ventilation system with renewable energy sources allows significant savings in operating as shown in the article.
\end{abstract}

Keywords: ground heat exchanger, ventilation, heat pump, heat source

\section{INTRODUCTION}

The modern standard of living makes a man demands increasing amount of indoor air quality. Conditions in which a person feels comfortable greatly affects not only his well-being, but also job performance, which translates into operating costs of the system. People spend large part their lives in closed spaces. This applies to both apartments, as well as rooms for work. Currently, in the newly constructed production facilities, of warehouse, office and public buildings air-conditioning and ventilation systems is a standard building equipment. Using air conditioning significantly improves conditions in the room, but it requires huge amounts of energy supply in order to function properly. Costs of production of thermal energy to heat the outside air to the value required for correct operation of air-conditioning systems may already be a heavy burden for the investor. However, these costs can be lowered by heat recovery systems from the exhaust air from the room. The paper has taken under consideration the systems based on alternative heat sources as ground. This renewable energy source are is to explore by air-conditioning systems by ground heat exchanger. In these circumstances the analysis of its transformation on Molier chart in many cases were presented.

\section{VENTILATION OF GROUND HEAT EXCHANGER, PLATE HEAT EXCHANGER AND A HEAT PUMP IN THE SUMMER}

Major requirements related to the amount of fresh air supplied, the effectiveness of its delivery and the simultaneous need to reduce energy consumption necessitate the use of mechanical ventilation with heat recovery option from exhaust air. The air removed from the building contains a large amount of heat that can be used to preheat the fresh ventilation air. In this way one can get a large savings related to the preparation of fresh ventilation air. Ventilation is crucial complement of ground heat exchanger. The initial treatment of outside air in the ground heat exchanger is substantially flattened from the amplitude of the temperature of ambient air. The result is not only increase living comfort but also significantly 
reduce the cost of energy. It allows to save operation cost and also can decreased investment costs associated with the air conditioning system to relatively large objects. The following is shown in a form of theoretical and computational methods for designing ventilation system which uses ground heat exchanger, plate type heat exchangers and heat pumps [1].

The air collected by the ambient air (Fig. 1) goes to ground air heat exchanger (GWC). In summer, ground heat exchanger captures the coolness accumulated in the soil during the winter, resulting in a significant reduction of ventilation air temperature. During the cooling of high air temperature and humidity, ground heat exchanger follows to condensation of water vapor. The air coming out of the GWC is then initially dried. This is a significant advantage because the lower humidity in the summer improves the feeling of comfort in a ventilated area. After cooling and drying in the ground heat exchanger, the air flows through the bypass of the heat exchanger and is vented into the building.

In Figure 2 is showed the transformation of moist air on Molier chart in ventilation system for the summer period with indicated processes: $\mathrm{ZO}$ - cooling and dehumidification of the supply air in ground heat exchanger, NP - air change of air in ventilated space.

This solution is preferred because of simple structure, but it may coolthe air in a ground air heat exchanger to low temperature (the state of the supply air - the point $O$ in Figure 1).

The proposals presented in Figure 3 rely on ambient air vented through the ground plate heat exchanger. After cooling and drying of air in GWC air flows through the panel from the plate heat exchanger. Then, the air is transported to central ventilation unit, where it is filtered, heated, supply to room and discharged through the exhaust duct outside of the building. The fresh air is sucked into the device where it passes through the filter that captures dust particles and allergens, grass pollen and others. Figure 4 is shown the course of changes in the air on ix moist air chart in the ventilation system for the summer period (Fig. 3). In Figure 4 indicated processes: $\mathrm{ZO}$ - cooling and dehumidification of the supply air heat exchanger in the ground, $\mathrm{ON}$ '- heating supply air cross heat exchanger, N'P'- change in the air in the room, P' $\mathrm{K}$ - change in exhaust air crossflow heat exchanger, the point $\mathrm{P}$ - state of the room air in the diagram in Figure 1.

The advantage is lower relative humidity in the room $\varphi_{\mathrm{P}},<\varphi_{\mathrm{P}}$ compared with the previous embodiment (Fig. 10). In this case, the amount of air supply can be increased.

\section{Principles of design of the ventilation system during the summer with GHE and cross heat exchanger}

Input data (summer period):

Ambient air parameters according to PN-76/B-03420 [8]:

- temperature $-\mathrm{t}_{\mathrm{z}},{ }^{\circ} \mathrm{C}$,

- relative humidity $-\varphi_{z}, \%$,

- specific enthaply of air $i_{z}, \mathrm{~kJ} / \mathrm{kg}$,

- humid ratio $-\mathrm{x}_{\mathrm{z}}, \mathrm{g} / \mathrm{kg}$.

Indoor air parameters according to PN-78/B-03421 [9]:

- indor air temperature $-\mathrm{t}_{\mathrm{p}},{ }^{\circ} \mathrm{C}$.

Technological parameters:

- total heat gains $-\mathrm{Q}_{\mathrm{C}}, \mathrm{kW}$,

- humid gain $-\mathrm{W}, \mathrm{kg} / \mathrm{h}$.

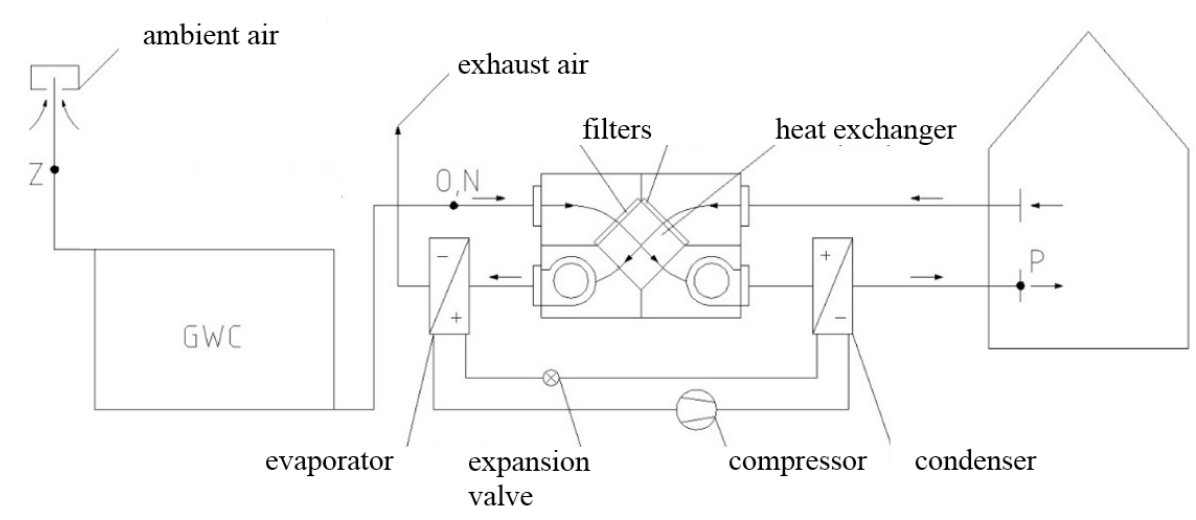

Fig. 1. Diagram of the ventilation system during the summer with ground air heat exchanger. Points of air condition Z, O, N, P, correspond to the air condition in the Molier chart (Fig. 2). 


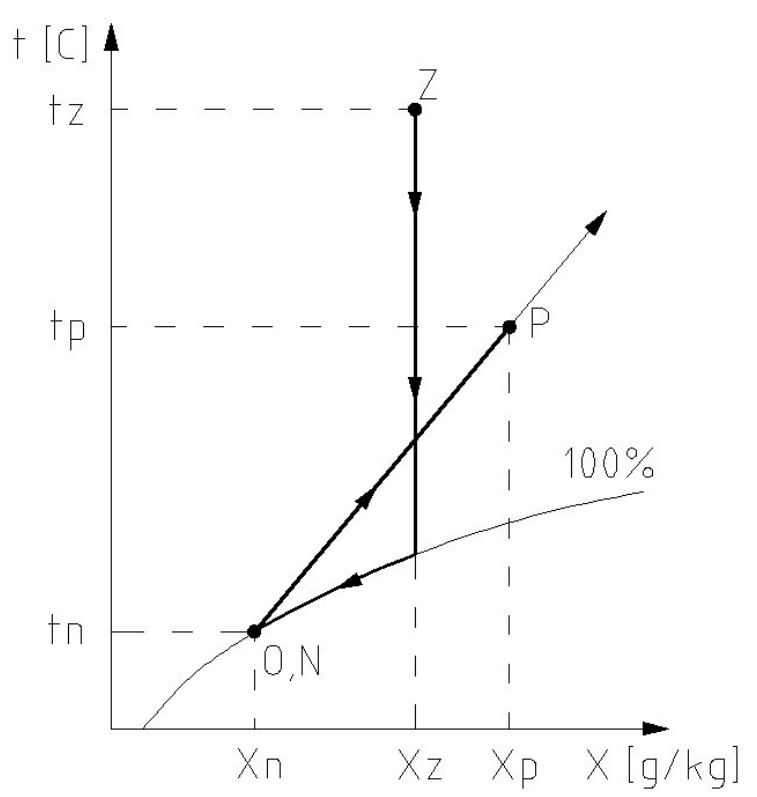

Fig. 2. The theoretical changes in the Molier chart of moist air in the ventilation system (system from Fig. 1) in the summer period

Designing processes for air ventilation system scheme is stated in Fig. 3, we start to build on the ix moist air chart (Fig. 4) entrusts the point of describing the state of the external $\mathrm{Z}\left(\mathrm{t}_{\mathrm{z}}, \varphi_{\mathrm{Z}}\right)$.

Next, assume that the temperature $\mathrm{t}_{\mathrm{O}}{ }^{\circ} \mathrm{C}$ (point $\mathrm{O}$ ) of the supply air after leaving the ground heat exchanger, wherein the air is cooled and dehumidified. It can be established temperature $t_{0}$ air stream in the GHE on the basis of catalog data of GHE system manufacturers and recommendations of literature in the summer on $10-15{ }^{\circ} \mathrm{C}$ lower than the outside air temperature $[2,3]$.

In order to obtain the point $\mathrm{A}$, first we run straight $\mathrm{x}_{\mathrm{Z}}=$ const intersection with the line $\varphi=$ $100 \%$, and then along line $\varphi=100 \%$ to the intersection with the straight $\mathrm{t}_{\mathrm{O}}=$ const (this process theoretical). In the literature there is no information about ZO process, to simplify the analysis assumes run along the line $\varphi=100 \%$.

Then, the airflow condition $\mathrm{O}$ is heated in a cross heat exchanger (process ON'). The location of point $\mathrm{N}$ defining the state of supply air is determined on the intersection of straight $\mathrm{x}_{\mathrm{O}}=$ const and $\mathrm{t}_{\mathrm{N}}{ }^{\prime}=$ const. The heating process air supply ON' may be carried out at high values of $\varphi$ relative humidity in the room (point $\mathrm{P}$ ) (without the use of the heat exchanger). In this case, by controlling the flow of air through the bypass of heat exchanger can reduce the relative humidity at the point $\mathrm{P}$.

The temperature $t_{\mathrm{N}}$ generally determined based on the heat exchanger efficiency $\eta$ from the equation:

$$
\eta=\left(t_{N^{\prime}}-t_{0}\right) /\left(t_{P}-t_{0}\right)
$$

After the transformation equation (1) we obtain the formula for temperature $t_{\mathrm{N}}$ :

$$
t_{N^{\prime}}=\eta \cdot\left(t_{P}-t_{O}\right)+t_{O}\left[{ }^{\circ} \mathrm{C}\right]
$$

The efficiency of the heat exchanger can assume $\eta=0.5-$ characteristic of this type of device.

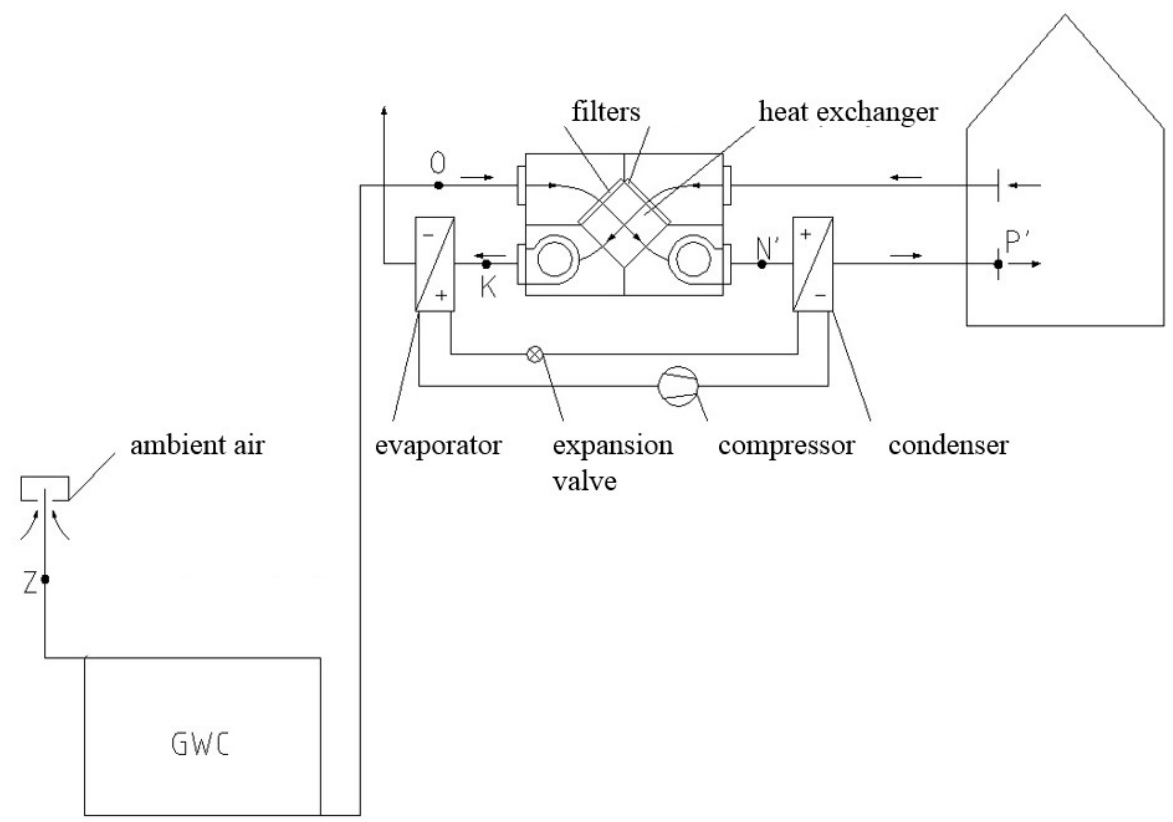

Fig. 3. Diagram of the ventilation system during the summer when operate ground air heat exchanger and cross heat exchanger. Points air condition Z, O, N ', P', Q correspond to the air condition in ix humid air chart (Fig. 4) 
The required amount of air volume flow into the building calculated according to the formula:

$$
G=Q_{C} /\left[\rho \cdot\left(i_{P^{\prime}}-i_{N^{\prime}}\right)\right],\left[m^{3} / h\right]
$$

where: $\rho$-air density, $\left[\mathrm{kg} / \mathrm{m}^{3}\right], \rho=1,2 \mathrm{~kg} / \mathrm{m}^{3}$,

$\mathrm{i}_{p}{ }^{\prime}, \mathrm{i}_{N^{\prime}}$ - specific enthalpy of air in point $\mathrm{P}^{\prime}$ i N' red from ix chart of humid air (Fig. 4).

Point P' corresponding to the parameters of indoor air can be determined at the intersection of line $t_{p}=$ const. and slope of the transformation of air condition $\varepsilon$, which we conduct through the point N'.

The slope coefficient of transformation of air condition $\varepsilon$ determined from the equation:

$$
\varepsilon=\frac{\mathrm{Q}_{\mathrm{C}}}{\mathrm{W}}\left[\frac{\mathrm{kJ}}{\mathrm{kg}}\right]
$$

We calculate the thermal power recovered in the cross heat exchanger with formula:

$$
Q_{1}=G \cdot \rho \cdot c_{p}\left(t_{N^{\prime}}-t_{O}\right)[k W]
$$

We calculate the cooling capacity of the ground heat exchanger with the following formula:

$$
Q_{2}=G \cdot \rho \cdot c_{p}\left(t_{Z}-t_{o}\right)[k W]
$$

\section{Example 1}

The parameters of external air PN-76 / B-03420 [8]:

- temperature $-\mathrm{t}_{\mathrm{z}}=30^{\circ} \mathrm{C}$,

- relative humidity $-\varphi_{\mathrm{Z}}=45 \%$

- air enthalpy $i_{z}=60 \mathrm{~kJ} / \mathrm{kg}$,

- moisture content $-\mathrm{x}_{\mathrm{Z}}=11.9 \mathrm{~g} / \mathrm{kg}$.

Indoor conditions according to PN-78 / B-03421 [9]:

- room temperature $-\mathrm{t}_{\mathrm{p}}=24^{\circ} \mathrm{C}$.

Technological parameters:

- total heat gains $-\mathrm{Q}_{\mathrm{C}}=0.92 \mathrm{~kW}$ gains moisture $-\mathrm{W}=0.55 \mathrm{~kg} / \mathrm{h}$.

In the graph ix moist air (Fig. 5) we select the point corresponding to the parameters of external air - point $\mathrm{Z}\left(30^{\circ} \mathrm{C}, 45 \%\right)$.

Next, assume that the temperature $\mathrm{t}_{\mathrm{O}}\left[{ }^{\circ} \mathrm{C}\right]$ (point $\mathrm{O}$ ) of the supply air after leaving the ground heat exchanger, wherein the air is cooled and dehumidified. The temperature is equal to $15^{\circ} \mathrm{C}$.

In order to obtain point $\mathrm{A}$, first we run straight $\mathrm{x}_{\mathrm{Z}}=11.9 \mathrm{~g} / \mathrm{kg}$ to intersect with the line $\varphi=100 \%$, then a line along the $\varphi=100 \%$ to the intersection with the straight $\mathrm{t}_{\mathrm{O}}=15^{\circ} \mathrm{C}$. Then, the airflow

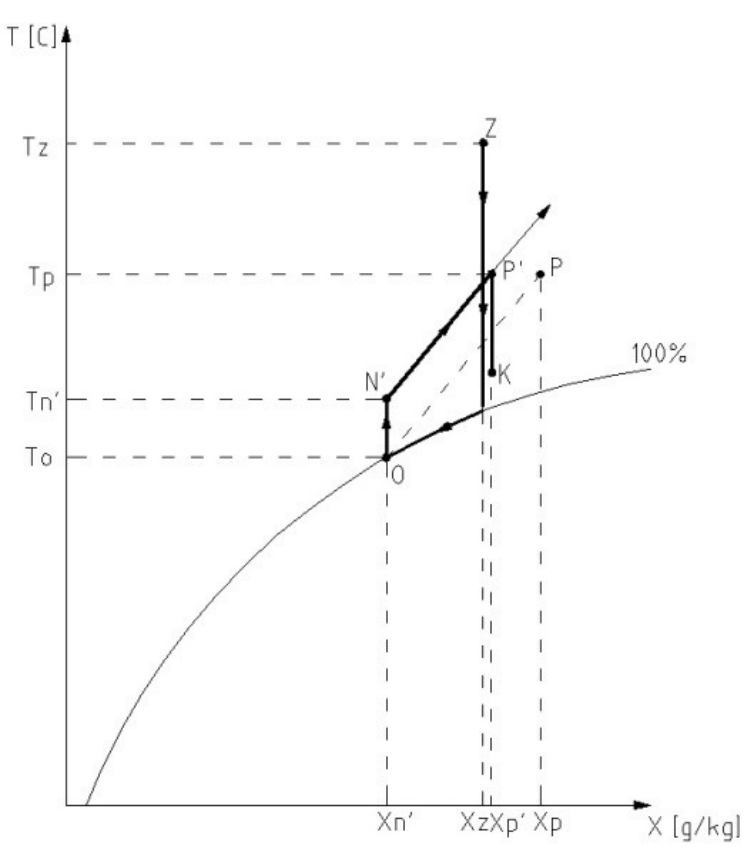

Fig. 4. The course of theoretical changes in the air on ix moist air chart in the ventilation system (Fig. 3) for the summer period.

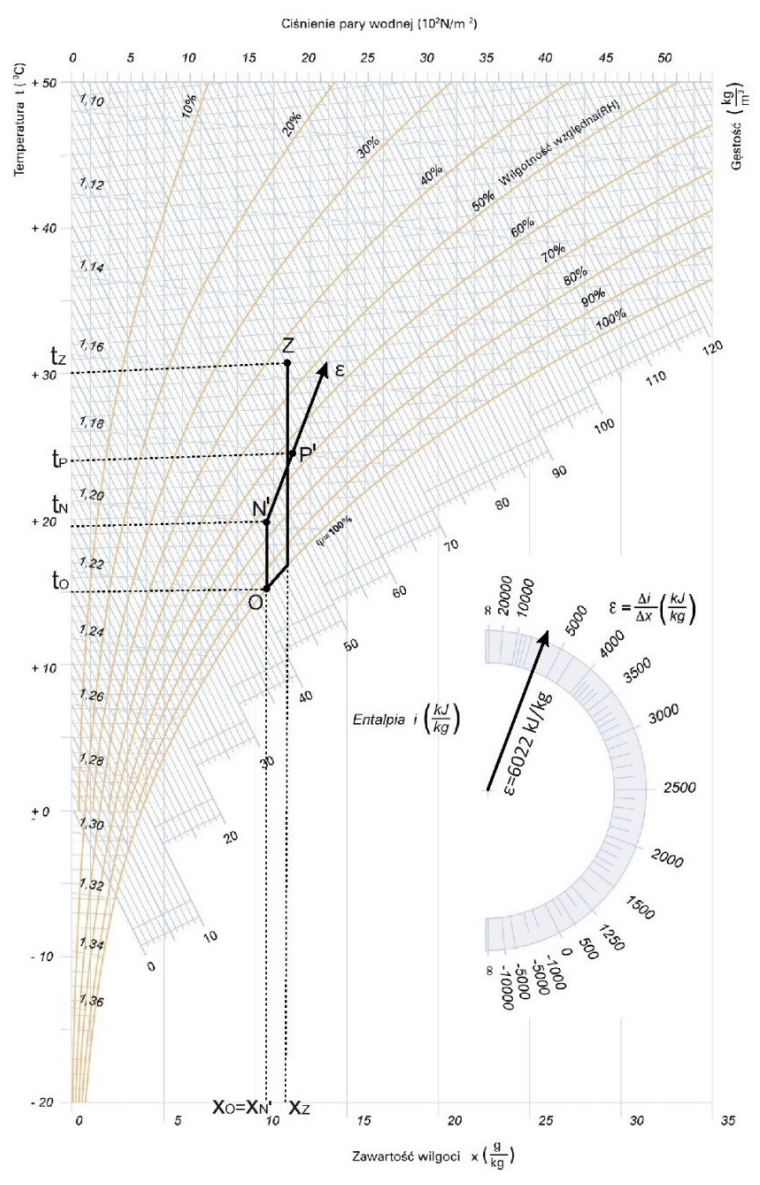

Fig. 5. The course of changes in the humid air in the ix chart of moist air for ventilation in the summer. 
condition $\mathrm{O}$ is heated in a cross heat exchanger (process ON'). The location of point N' defining the state of supply air is determined on the intersection of straight $\mathrm{x}_{\mathrm{O}}=$ const and $\mathrm{t}_{\mathrm{N}}=$ const.

The temperature $t_{\mathrm{N}}$, determined from the equation (2) (assumed $\eta=0.5$, the selection of air handling unit with plate heat exchanger should specify parameter $\eta)$ :

$$
\mathrm{t}_{\mathrm{N}}=0,5 \cdot(24-15)^{\circ} \mathrm{C}+15^{\circ} \mathrm{C}=19,5^{\circ} \mathrm{C}
$$

The required amount of air blown into the building is calculated from equation (3) (ix diagram of wet air in Fig. 5 is read $\mathrm{i}_{\mathrm{p}}{ }^{\prime}=54,5 \mathrm{~kJ} / \mathrm{kg}$, $\left.\mathrm{i}_{\mathrm{N}}{ }^{\prime}=46 \mathrm{~kJ} / \mathrm{kg}\right)$ :

$\mathrm{G}=0,92 \mathrm{~kW} /\left[1,2 \mathrm{~kg} / \mathrm{m}^{3} \cdot(54,5-46) \mathrm{kJ} / \mathrm{kg}\right]=$ $0,09 \mathrm{~m}^{3} / \mathrm{s}=325 \mathrm{~m}^{3} / \mathrm{h}$

Point $\mathrm{P}^{\prime}$ corresponding to the parameters of indoor air can be determined at the intersection of the $\mathrm{t}_{\mathrm{p}}=24{ }^{\circ} \mathrm{C}$ and the slope of the transformation of air condition $\varepsilon$, which we conduct through the point N'. Substituting the data to the equation (4), we get:

$$
\varepsilon=\frac{0,92}{0,55}=6022 \frac{\mathrm{kJ}}{\mathrm{kg}}
$$

We calculate the thermal power recovered in the cross heat exchanger from the formula (5):

$\mathrm{Q}_{1}=0,09 \cdot 1,2 \cdot 1 \cdot(19,5-15)=0,49 \mathrm{~kW}$

We calculate the thermal power in ground heat exchanger from the formula (6):

$\mathrm{Q}_{2}=0,09 \cdot 1,2 \cdot 1(30-15)=1,62 \mathrm{~kW}$

Since the obtained parameters of the point $\mathrm{P}^{\prime}$ are satisfactory, therefore, there is no need to turn the heat pump. The proposals in the diagram (Fig. 6) charged by the air intake air goes into the ground to air heat exchanger. After cool- ing and drying GHE air flows through the panel from the plate heat exchanger. The cross heat exchanger supply air is heated at the expense of the exhaust air heat. If the supply air parameters are not sufficient, the heat pump compressor system is turned on.

The task of the compressor absorbs (through one of the heat exchangers - evaporator) heat from exhaust air - lower heat source and transfer it (the second heat exchanger - condenser) to the supply air, so-called the upper heat source. The heat pump condenser supply air is additionally heated. The heated air is blown into the building. In Fig. 5 is presented course changes in the air on a ix chart of moist air in the ventilation system for the summer period. In Figure 6 indicated processes: $\mathrm{ZO}$ - cooling and dehumidification of the supply air in the ground heat exchanger ON'- heating supply air heat exchanger cross, N'N"'- heating supply air in the heat pump, N"P"- change in the air in the room, $\mathrm{P}$ " $\mathrm{K}$ - heat transfer by cross-supplied air heat exchanger, KT - supplied air heat transfer through the heat pump, the point $\mathrm{P}$ - the state of indoor air ventilation system at work according to the diagram in Figure 6, the point $\mathrm{P}^{\prime}-$ air condition room in the diagram in Figure 3.

The advantage of this solution can lower the relative humidity in the room $\varphi_{\mathrm{P}}{ }^{\prime \prime}<\varphi_{\mathrm{P}}{ }^{\prime}<\varphi_{\mathrm{P}}$ compared with a previous (Fig. 2 and 4). However, in this case, the amount of air supply can be increased.

The design method ventilation system according to the diagram in 6 design method is similar to the diagram in Figure 3 with the exception of the heat pump, which will be examined further on another embodiment (in the winter).

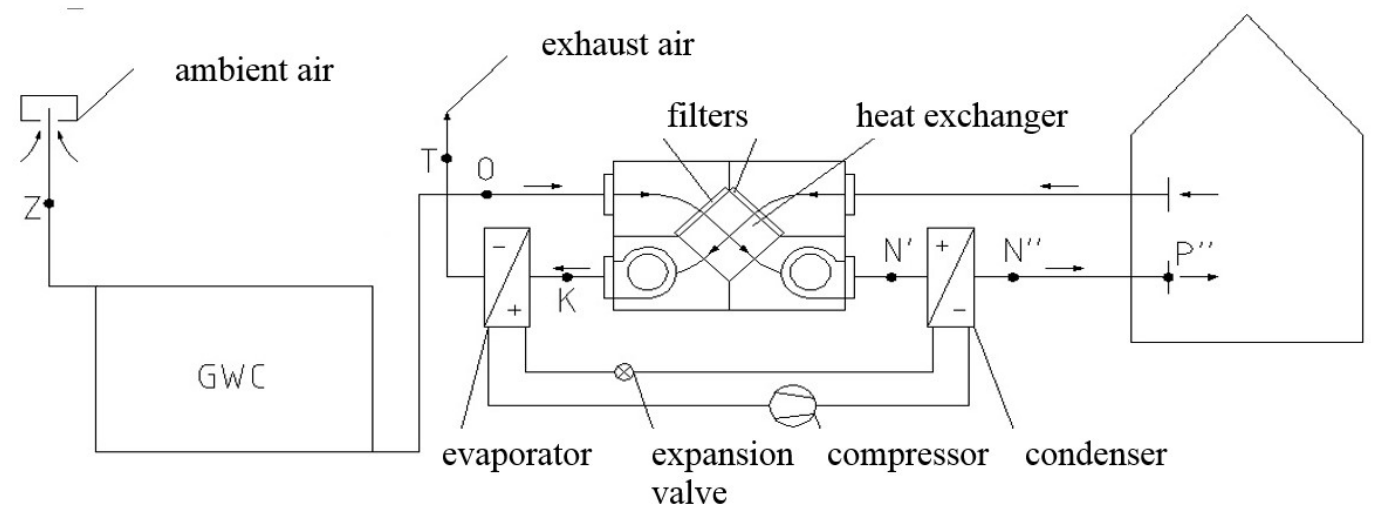

Fig. 6. Diagram of the ventilation system during the summer months when ground air heat exchanger, cross-flow exchanger and a heat pump are running. Points air condition $\mathrm{Z}, \mathrm{O}, \mathrm{N}$ ', N' ', P' ', T' correspond to the state of the air in the ix chart of humid air (Fig. 7) 


\section{VENTILATION WITH GROUND HEAT EXCHANGER, CROSS HEAT EXCHANGER AND A HEAT PUMP IN THE WINTER}

The air collected by the air intake (Fig. 8) goes to ground air heat exchanger. In the winter, ground heat exchanger captures, accumulated during the summer heat in the ground, through which cold air is heated. A well-designed and manufactured GHE regardless of external conditions heats the ventilation air after the data directory of manufacturers and well-known literature sources to approx. $+2{ }^{\circ} \mathrm{C}[4,5]$. This gives you the opportunity to significantly reduce the investment costs of the heating system, boiler plant's power as well as continuous and increasing operational savings. The ground heat exchanger is still the property, when it is cold outside the air is humidificated and heated. This process occurs as a result of capillary soil, but can also be supported by the installation of spraying deposit accumulation. After warming and moistening the GHE air is blown into the building.

In Figure 9 is presented course changes in the air on a ix chart of moist air in the ventilation system (Fig. 8) for the winter period. In Figure 9 indicated processes: $\mathrm{ZO}$ - heating supply air in the ground heat exchanger, NP - change in the air in the room.

This solution is preferred because of simple structure, but it may be that the temperature of supply air $t_{\mathrm{N}}$ ground after heating in the heat exchanger is too low.

The proposals in Figure 10 charged by the air intake air goes into the ground to air heat exchanger. After heating and humidification in the GWC air flows through the control panel with plate heat exchanger. In cross-supply air heat exchanger is heated at the expense of the exhaust air heat. Figure 11 is shown the course of changes in the air on a graph ix moist air in the ventilation system (Fig. 10) for the winter period. In Figure 11 indicated processes: $\mathrm{ZO}$ - heating supply air in the ground heat exchanger ON'- heating supply air cross heat exchanger, N'P' - change in the air in the room, P' $\mathrm{K}$ - change in exhaust air cross heat exchanger, point $\mathrm{P}$ - the state of air in the room in the diagram in Figure 7. Supplied air heat transfer by rotary heat exchanger. The disadvantage of this solution can lower the

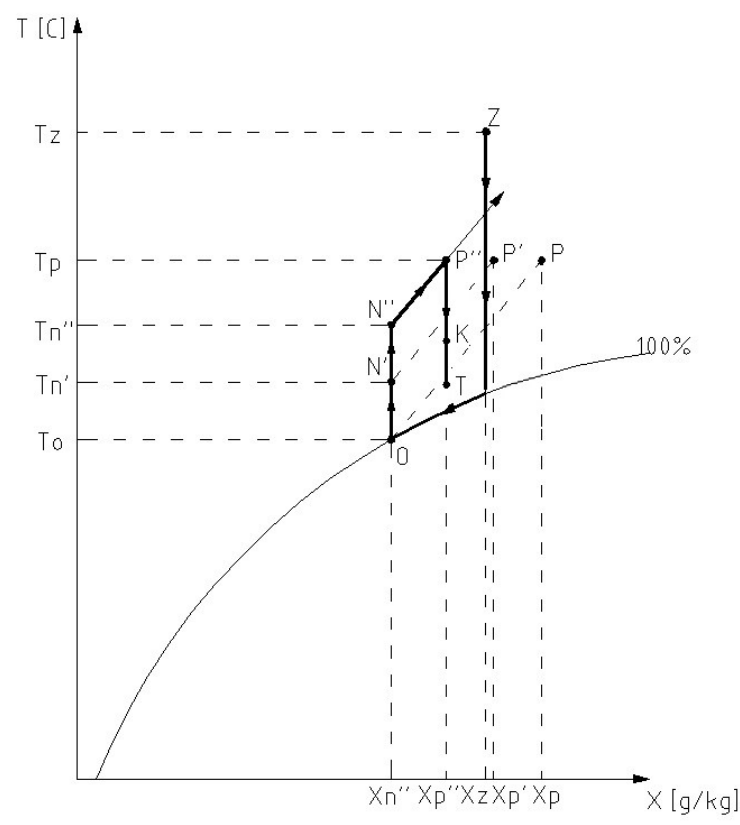

Fig. 7. The course of theoretical changes in the air on a ix chart of moist air in the ventilation system

(Fig. 6) for the summer period.

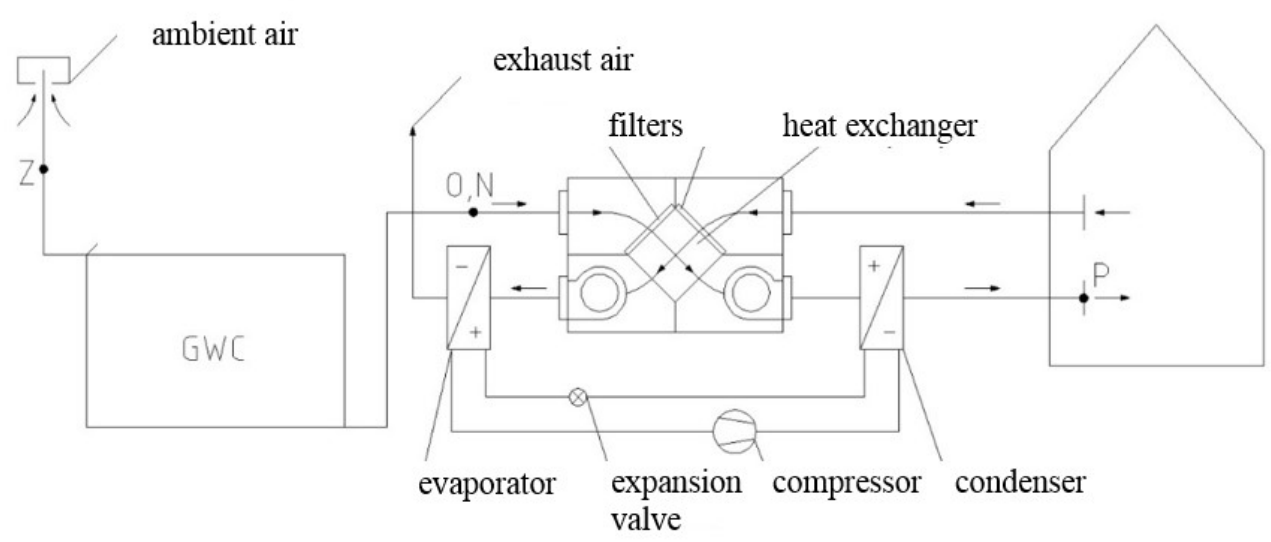

Fig. 8. Diagram of the ventilation system during the winter with only ground running air heat exchanger. Points air condition Z, O, N, P, correspond to the air condition in the ix humid air chart (Fig. 9). 
relative humidity of the room in comparison with the previous solution (Fig. 8).

The proposals in the diagram (Fig. 12) air collected by the air intake goes to ground air heat exchanger. After heating and humidification in the GHE air flows through the control panel with plate heat exchanger. The cross heat exchanger supply air is heated at the expense of the exhaust air heat. If the supply air parameters are not sufficient, is activated heat pump compressor. The supply air is warmed up in the condenser, at the expense of the heat of the exhaust air $[6,7]$.

Figure 13 is shown the course of changes in the air on a ix chart of moist air in the ventilation

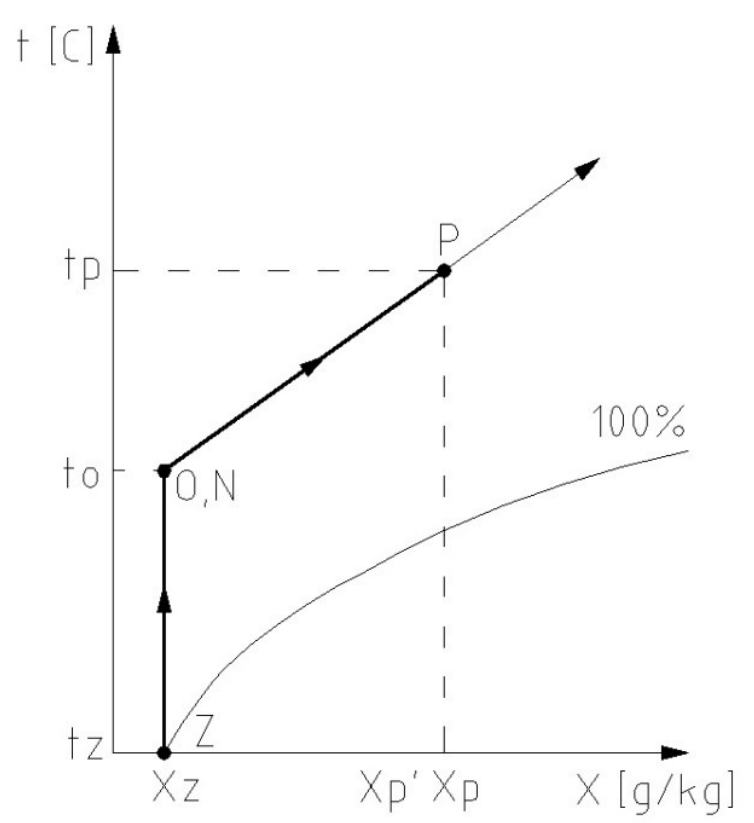

Fig. 9. The course of theoretical changes in the air on a ix moist air chart in the ventilation system for the winter period system (Fig. 12) for the winter period. In Figure 13 indicated processes: $\mathrm{ZO}$ - heating supply air in the ground heat exchanger ON'- heating supply air in cross heat exchanger, N'N"' heating supply air in the heat pump, N"P"- change indoor air, PK - heat transfer by cross-supplied air heat exchanger, KT - supplied air heat transfer through the heat pump, the point $\mathrm{P}$ - the state of air in the room in the diagram in Fig. 8, the point P'- the state of air in the room in the diagram on Fig. 10.

The disadvantage of this solution can lower the relative humidity in the room $\varphi_{\mathrm{P}},<\varphi_{\mathrm{P}},<\varphi_{\mathrm{P}}$ compared with earlier solutions, in this case, the amount of air supply can be increased.

\section{Principles of design of the ventilation system during the winter}

Output (winter period):

The parameters of external air PN-76 / B-03420 [8]:

- temperature $-\mathrm{t}_{\mathrm{z}},{ }^{\circ} \mathrm{C}$,

- relative humidity $-\varphi_{z}, \%$

- air enthalpy $\mathrm{i}_{\mathrm{z}}, \mathrm{kJ} / \mathrm{kg}$,

- moisture content $-\mathrm{x}_{\mathrm{Z}} \mathrm{g} / \mathrm{kg}$.

Indoor conditions according to PN-78 / B-03421 [9]:

- room temperature $-\mathrm{t}_{\mathrm{p}}{ }^{\circ} \mathrm{C}$.

Technological parameters:

- heat gains in total $-\mathrm{Q}_{\mathrm{C}} \mathrm{kW}$,

- gains moisture $-\mathrm{W}, \mathrm{kg} / \mathrm{h}$,

- amount of ventilation air (summer period) $-\mathrm{G} \mathrm{m}^{3} / \mathrm{s}$.

Designing processes for air ventilation system scheme is stated in Figure 13, we start to build on the chart ix moist air (Fig. 12) entrusts

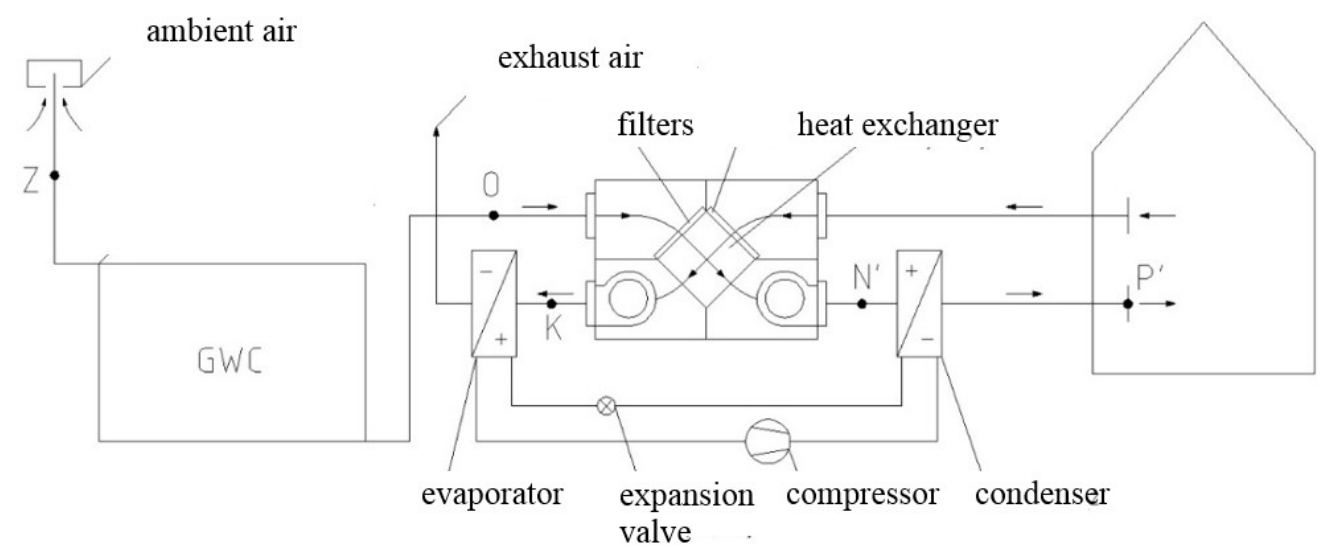

Fig. 10. Diagram of the ventilation system during the winter when ground air heat exchanger and cross heat exchanger are running. Points air condition $\mathrm{Z}, \mathrm{O}, \mathrm{N}$ ', $\mathrm{P}$ ', Q correspond to the air condition in the ix humid air chart (Fig. 3) 


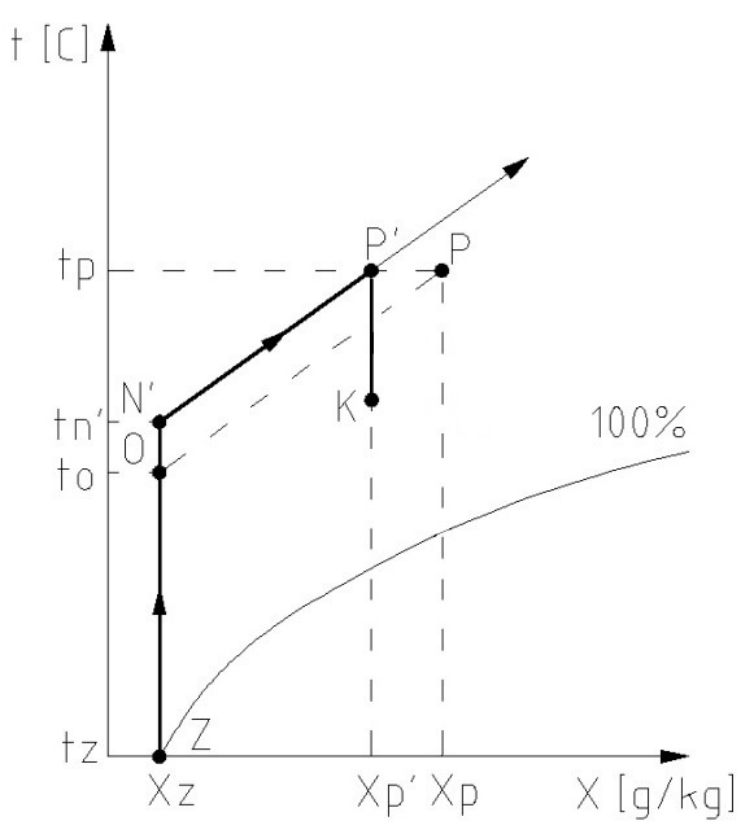

Fig. 11. The course of changes in the air on ix chart of moist air in the ventilation system (10) for the winter period

the point of describing the state of the external $\mathrm{Z}\left(\mathrm{t}_{\mathrm{z}}, \varphi_{\mathrm{Z}}\right)$. Then insert the temperature $\mathrm{t}_{\mathrm{O}}\left[{ }^{\circ} \mathrm{C}\right]$ (point $\mathrm{O}$ ) air stream after leaving the ground heat exchanger, where the air is heated and humidified. The temperature was found to be $2{ }^{\circ} \mathrm{C}$ on the basis of catalog data GHE system manufacturers and recommendations literature. The point we get to the intersection of the $\mathrm{x}_{\mathrm{Z}}=$ const and the $\mathrm{t}_{\mathrm{o}}=$ const. Then, the airflow condition $\mathrm{O}$ is heated in a cross heat exchanger (process ON'). The location of point N' defining the state of supply air is determined on the intersection of straight $\mathrm{x}_{\mathrm{O}}=$ const and the $\mathrm{t}_{\mathrm{N}}=$ const. by adjusting the air flow to bypass the heat exchanger can be adjusted decrease the relative humidity of indoor air in the room. The temperature $t_{\mathrm{N}}$, determined from the equation (2):

$$
t_{N^{\prime}}=\eta \cdot\left(t_{P}-t_{O}\right)+t_{O}\left[{ }^{\circ} \mathrm{C}\right]
$$

Cross flow heat exchanger was adopted $\eta=0.5-$ characteristic of this type of device. The moisture content of indoor air can be calculated with the following formula:

$$
x_{P \prime \prime}=x_{Z}+\frac{W_{Z}}{G \cdot \rho_{P}}\left[\frac{g}{k g}\right]
$$

Point $\mathrm{P}^{\prime}$ is obtained at the intersection of line $\mathrm{x}_{\mathrm{P}}=$ const with the line $\mathrm{t}_{\mathrm{P}}=$ const.

Supply point $\mathrm{N}$ one get to the intersection of the line $\mathrm{x}_{\mathrm{N}}=$ const and slope of the process of $\varepsilon$, which is then converted by a point $\mathrm{P}$ ".

The slope coefficient of transformation of air condition $\varepsilon$ determined from the equation (4):

$$
\varepsilon=\frac{\mathrm{Q}_{\mathrm{C}}}{\mathrm{W}}\left[\frac{\mathrm{kJ}}{\mathrm{kg}}\right]
$$

We calculate the thermal power recovered in the cross heat exchanger from the formula (5):

$$
Q_{1}=G \cdot \rho \cdot c_{p}\left(t_{N^{\prime}}-t_{O}\right)[k W]
$$

Thermal power recovered in the condenser heat pump is determined by the formula:

$$
Q_{s k r}=G \cdot \rho \cdot c_{p} \cdot\left(t_{N \prime \prime}-t_{N \prime}\right)[k W]
$$

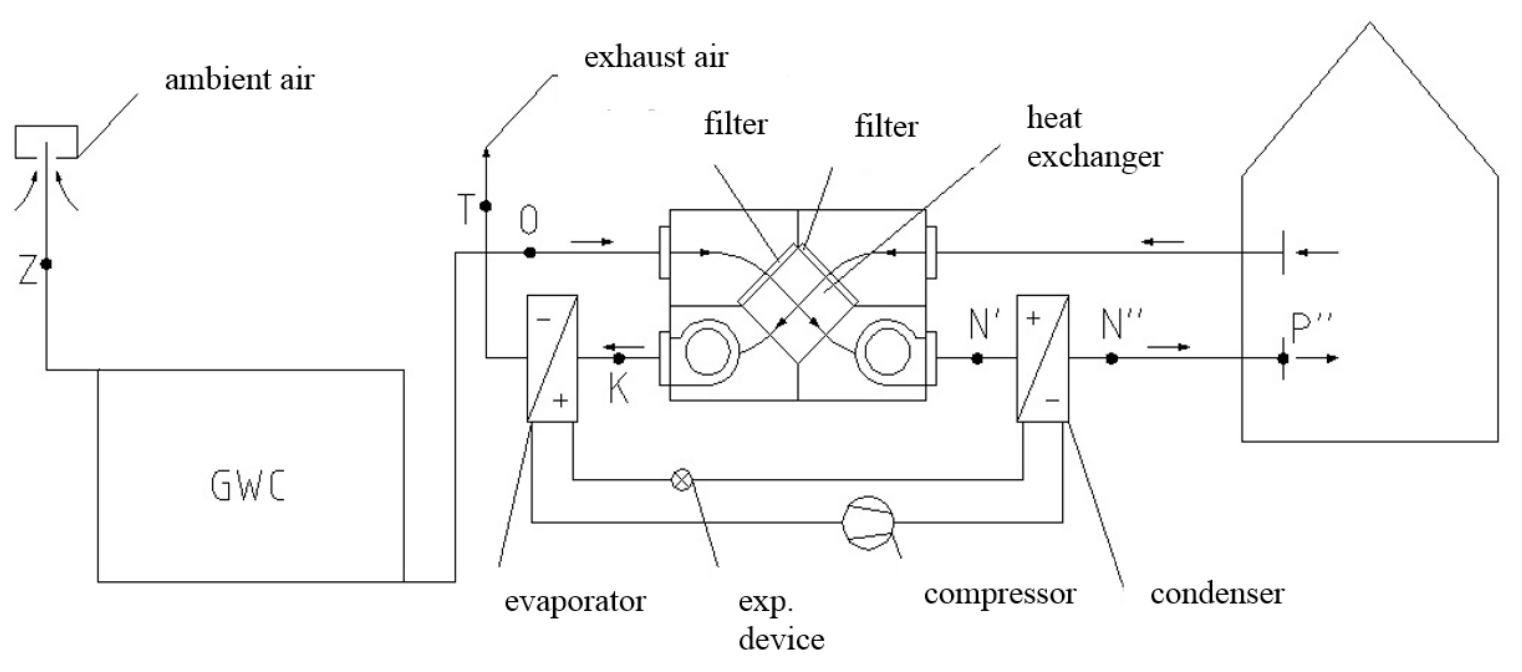

Fig. 12. Diagram of the ventilation system during the winter when ground air heat exchanger, cross-flow exchanger and a heat pump are running. Points air condition Z, O, N', N', P', Q, T correspond to the air condition in the ix humid air chart (Fig. 13). 


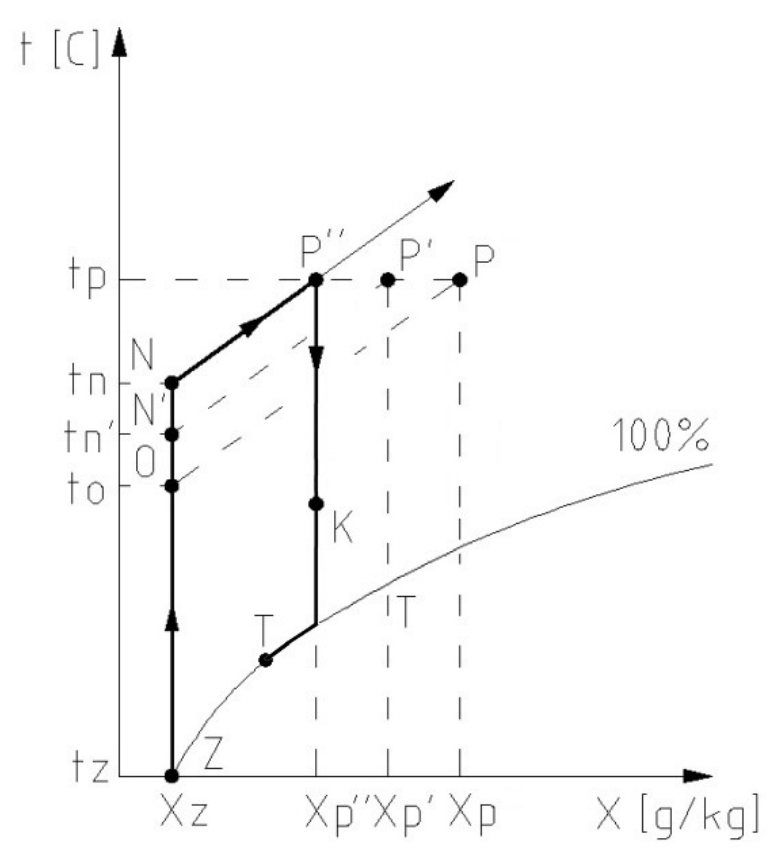

Fig. 13. The course of theoretical changes in the air on a ix chart of moist air in the ventilation system (Fig. 12) for the winter period.

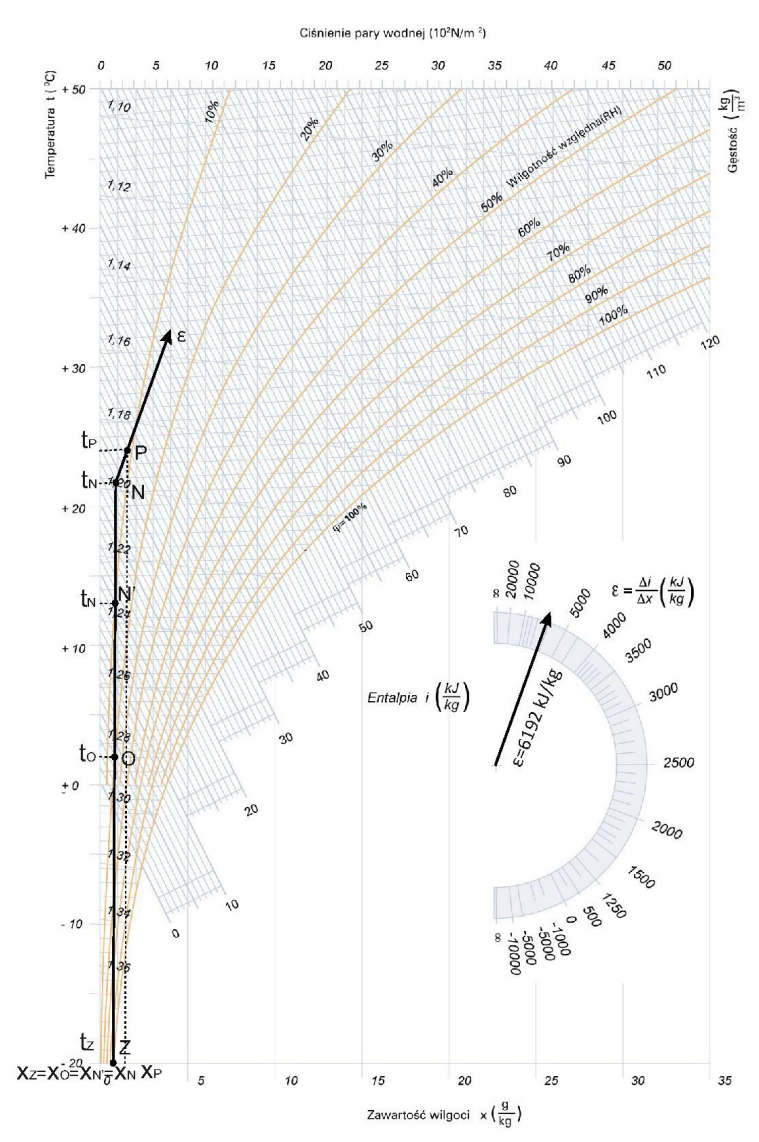

Fig. 14. The course of changes in the humid air in the ix chart of moist air for ventilation during the winter (eg. 2)
We calculate the thermal power in ground heat exchanger from the formula (6):

$$
Q_{2}=G \cdot \rho \cdot c_{p}\left(t_{o}-t_{Z}\right)[k W]
$$

\section{Example 2}

The parameters of external air PN-76 / B-03420 [8]:

- temperature $-\mathrm{t}_{\mathrm{z}}=-20{ }^{\circ} \mathrm{C}$,

- relative humidity $-\varphi_{z}=100 \%$

- air enthalpy $\mathrm{i}_{\mathrm{z}}=-18.4 \mathrm{~kJ} / \mathrm{kg}$,

- moisture content $-\mathrm{x}_{\mathrm{Z}}=0.8 \mathrm{~g} / \mathrm{kg}$.

Indoor conditions according to $\mathrm{PN}-78$ / B-03421 [9]:

- room temperature $-\mathrm{t}_{\mathrm{p}}=24{ }^{\circ} \mathrm{C}$.

Technological parameters:

- total heat gains $-\mathrm{Q}_{\mathrm{C}}=0.43 \mathrm{~kW}, \mathrm{Q}=0.92 \mathrm{~kW}$ (during the summer)

- moisture gains $-\mathrm{W}=0.25 \mathrm{~kg} / \mathrm{h}$,

- amount of ventilation air (summer period) $-\mathrm{G}=325 \mathrm{~m}^{3} / \mathrm{h}$.

In the ix chart of moist air (Fig. 14), select the point corresponding to the parameters of external air - point $\mathrm{Z}\left(-20^{\circ} \mathrm{C}, 100 \%\right)$.

Then insert the temperature $\mathrm{t}_{\mathrm{O}}\left[{ }^{\circ} \mathrm{C}\right]$ (point $\mathrm{O}$ ) air stream after leaving the ground heat exchanger, where the air is heated and humidified. It was founded temperature is equal to $2{ }^{\circ} \mathrm{C}$. The point we get to the intersection of the $\mathrm{x}_{\mathrm{z}}=0.8 \mathrm{~g} / \mathrm{kg}$ and the $\mathrm{t}_{\mathrm{O}}=2{ }^{\circ} \mathrm{C}$. Then, the airflow condition $\mathrm{O}$ is heated in the cross (the process ON'). The location of point N' defining the state of supply air is determined on the intersection of straight $\mathrm{x}_{\mathrm{O}}=0.8$ $\mathrm{g} / \mathrm{kg}$ and $\mathrm{t}_{\mathrm{N}}=13{ }^{\circ} \mathrm{C}$. Cross flow heat exchanger was adopted $\eta=0.5$.

The temperature $t_{N}$, determined from the equation (2):

$$
t_{N^{\prime}}=0,5 \cdot(24-2)+2=13^{\circ} \mathrm{C}
$$

The location of point P' defining the characteristics of indoor air is calculated from equation (8):

$$
x_{P \prime \prime}=0,8+\frac{250}{324 \cdot 1,2}=1,4 \frac{\mathrm{g}}{\mathrm{kg}}
$$

Point $\mathrm{P}^{\prime}$ is obtained at the intersection of line $\mathrm{x}_{\mathrm{P}}=1.4 \mathrm{~g} / \mathrm{kg}$ of line $\mathrm{t}_{\mathrm{P}}=24{ }^{\circ} \mathrm{C}$. Supply point $\mathrm{N}^{\prime}$ get at the intersection of the line $\mathrm{x}_{\mathrm{N}}=0.8 \mathrm{~g} /$ $\mathrm{kg}$ and slope of the process of $\varepsilon$, which is then 
converted by a point $\mathrm{P}$ ". The slope coefficient of transformation of air condition $\varepsilon$ is calculated from equation (4):

$$
\varepsilon=\frac{0,43}{0,25}=6192 \frac{\mathrm{kJ}}{\mathrm{kg}}
$$

Supply air temperature $t_{N}=22,6^{\circ} \mathrm{C}$ (read from Fig. 14). We calculate the thermal power recovered in the cross heat exchanger from formula (5): $\mathrm{Q}_{1}=0,09 \cdot 1,2 \cdot 1 \cdot(13-2)=1,19 \mathrm{~kW}$

We calculate the thermal power recovered in the condenser heat pump from the formula (9):

$\mathrm{Q}_{\mathrm{skr}}=0,09 \cdot 1,2 \cdot 1 \cdot(22,6-13)=1,04 \mathrm{~kW}$

We calculate the thermal power in ground heat exchanger from (6):

$\mathrm{Q}_{1}=0,09 \cdot 1,2 \cdot 1(2-(-20))=2,38 \mathrm{~kW}$

For the calculated air flow vented $G=327$ $\mathrm{m}^{3} / \mathrm{h}$ was selected panel of plate heat exchanger and a heat pump - Heat Recovery Unit MISTRAL GEO 400, which cooperates with the GHE ground heat exchanger [11]. Technical data MISTRAL RECUPERATOR GEO 400:

- volume of supply air - 300-450 $\mathrm{m}^{3} / \mathrm{h}$,

- external static pressure (supply) - 175-300 Pa,

- the temperature efficiency of the air handling unit $-81-91 \%$

- power consumption - 40-290 W.

As variant can be selected monoblock device CLIVET CPAN- U 3-9 [10] for the treatment of fresh air with the function of heating and cooling recovery from exhaust air (heat pump). Cooling capacity $1.66-3.92 \mathrm{~kW}$ heating capacity of $1.66-4.48 \mathrm{~kW}$ fan static pressure of $40 \mathrm{~Pa}$.

The length of ground-air heat exchanger tube determined from the formula:

$$
L=\frac{Q}{q_{j}}[\mathrm{~m}]
$$

where: $\mathrm{Q}$ - thermal power ground heat exchanger [W]

$\mathrm{q}_{\mathrm{j}}$ - the amount of energy extracted from the ground with one meter of the current channel $[\mathrm{W} / \mathrm{m}]$.

It was assumed that the ground heat with one meter of soil collected 25.0 watts of power.

$$
L=\frac{2380}{25,0}=96 \mathrm{~m}
$$

The length of ground-air heat exchanger is $96 \mathrm{~m}$.

\section{CONCLUSION}

This paper describes the possibility of using ground heat exchanger cooperating with a ground heat pump systems used in residential buildings. The presented method of calculation allows for a relatively easy and simple way to determine the main technical parameters of the system, such as the powers of the devices, the air temperature in different places of air treatment system. The presented calculations show that the length of ground heat exchanger does not exceed $100 \mathrm{~m}$, which gives great opportunities to blend into the architecture of the area, which is considered the building without problems of lack of surface to ensure the thermal power generated from the ground. This suggests that the proposed solution may be an alternative in relation to the already commonly used ventilation systems with GHE, enriched with a heat pump system allowing for additional heat recovery and also allows space cooling in the summer period, which greatly increases the thermal comfort in the building.

\section{REFERENCES}

1. Andrew D. 2013. Modern Refrigeration and Air Conditioning. Goodheart-Willcox; Nineteenth Edition, June 27.

2. Bokalders V., Block M. 2012. The Whole Building Handbook, Earthscan London.

3. Kreith F. 2001. Handbook of heating, ventilation, and air conditioning, CRC Press.

4. Roaf S. 2013. Ecohouse, a design guide, Routledge - Taylor \& Francis Group, London.

5. Tymkow P. 2013/ Building services design for energy efficient buildings, Taylor \& Francis Group, New York.

6. Ochsner K. 2008. Geothermal Heat Pumps, Taylor \& Francis Group, London.

7. Jenkins D. 2013. Renewable Energy Systems, Taylor \& Francis Group, Routledge.

8. PN-76/B-3420: Wentylacja i klimatyzacja. Parametry obliczeniowe powietrza zewnętrznego.

9. PN-78/B-03421: Wentylacja i klimatyzacja. Parametry obliczeniowe powietrza wewnętrznego w pomieszczeniach przeznaczonych do stałego przebywania ludzi.

10. http://vtsgroup.pl/

11. http://www.pro-vent.pl/ 